\title{
Further studies of an intravasal copper device in rats
}

\author{
Roomana K. Ahsan, M. M. Kapur, A. Farooq and K. R. Laumas \\ Department of Reproductive Biology \& Surgery, All India Institute of Medical Sciences, \\ New Delhi, India
}

\begin{abstract}
Summary. A $1.5 \mathrm{~cm}$ long copper wire caused complete inhibition of fertility in male rats when placed properly in the vasal lumen. The contraceptive effectiveness of the device was directly proportional to the surface area of the device and was non-obstructive. The release rate of copper in vivo from a $1.5 \mathrm{~cm}$ long wire was 11.6 $\mu \mathrm{g} / \mathrm{day}$ during the first month and $6.8 \mu \mathrm{g} / \mathrm{day}$ over the first 3 months. The contraceptive action of the wire starts about 20 days after insertion. Fertility was regained in $67 \%$ of the rats by 90 days after removal of the device. Similar devices of stainless steel and silver did not affect fertility.
\end{abstract}

\section{Introduction}

The development of a non-occlusive intra-vas device for the control of male fertility has been reported (Ahsan, Farooq, Kapur \& Laumas, 1976). However, more detailed information on the relationship between the surface area of the copper device and its contraceptive effectiveness, the expected life-span of the device, and the reversibility of the method was required before further development of this long-term method for male contraception.

This paper presents our results on the contraceptive effectiveness of devices of different surface areas and the most effective device was further evaluated.

\section{Materials and Methods}

Rats of the Wistar strain were obtained from the departmental breeding colony. Young adult males weighing $200-250 \mathrm{~g}$ and females weighing $150-200 \mathrm{~g}$ were all of proven fertility.

The copper device was in the form of a wire of $0.14 \mathrm{~mm}$ in diameter, obtained from Mackay Inc., New York, U.S.A. The purity of the wire was checked before use and was found to be $99 \%$ pure. The $0.14 \mathrm{~mm}$ diameter steel wire was surgical grade, obtained from the operating theatre of the AIIMS Hospital. The silver wire was obtained from Ventron Corporation, U.S.A.

With ether anaesthesia and sterile conditions, the vas deferens was exposed through a small mid-line incision in the lower abdomen. The middle third of the vas was stretched on a pair of forceps and the device was introduced from the urethral end of the vas, with its free end facing towards the epididymis. To prevent displacement, a loose knot was made with the thread attached to a loop at the other end. The vas was returned to the abdomen which was closed in two layers using $3 / 0$ cat gut. An i.m. injection of 50000 units procaine penicillin was given. For sham-operated animals (controls) the above procedure was followed exactly except that the device was removed immediately after introduction into the vas.

In Exp. I the effects of different lengths of the copper wire on fertility of male rats was studied for 120 days. The surface areas of the $0.5,1.0$ and $1.5 \mathrm{~cm}$ lengths of wire were calculated as 
being $2.2,4.4$ and $6.6 \mathrm{~mm}^{2}$. In Exp. II the effect of a $1.5 \mathrm{~cm}$ copper wire was compared with that of stainless-steel and silver wires of the same length and diameter. In Exp. III, the release rate of copper from devices inserted for 1 to 3 months was determined. The onset of contraceptive action was determined in Exp. IV. The performance of 12 rats with a $1.5 \mathrm{~cm}$ copper device and of 5 sham-operated rats was evaluated from 11 to 70 days after operation. In Exp. $V$ the fertility of males which had had a $1.5 \mathrm{~cm}$ copper device inserted for 70 days was examined over a period of 31-90 days from the time of removal of the device.

To remove the device a similar operative technique was used. The end of the device was located by the thread and the granuloma was carefully punctured, the contents extruded and the vas was cleaned. The device and thread were removed. A fine suture $(6 / 0$ thread) was sometimes required to close the puncture site.

The procedure for testing the fertility of the rats was exactly as described by Ahsan et al. (1976), i.e. laparotomy of females at Day 10 after mating. All mating studies were started 30 days after insertion of the device except for Group IV when matings were arranged 10 days after insertion of the device. Positive matings were recorded by the presence of spermatozoa in the vaginal smears.

The devices recovered after 1 and 3 months were weighed and dissolved in concentrated nitric acid and further diluted with deionized double-distilled water for estimation of copper concentration using an atomic absorption spectrophotometer (Beckman Model 495). Uninserted devices were used as control for this part of the study.

\section{Results}

\section{Effects of different lengths of copper wire}

The results are shown in Table 1 . The $1.5 \mathrm{~cm}$ wire was totally effective but the results with the 0.5 and $1.0 \mathrm{~cm}$ lengths showed an incomplete antifertility effect which seemed to alter with duration of insertion. At autopsy of these males, the device was confirmed to be in the vasal lumen in all the infertile animals but was missing completely from one or both sides in all the fertile animals. The missing device was sometimes located inside the granuloma. A plot of the percentage fertility and the surface area of the copper wire gave a regression equation of $y=14.40 x+96.46(r=0.99)$.

Table 1. Fertility performance of male rats with intravasal copper wires of various lengths

\begin{tabular}{ccccccc}
\hline $\begin{array}{c}\text { Length of } \\
\text { wire } \\
\text { (cm) }\end{array}$ & $\begin{array}{c}\text { No. of } \\
\text { animals }\end{array}$ & $\begin{array}{c}\text { Duration of } \\
\text { treatment } \\
\text { (days) }\end{array}$ & $\begin{array}{c}\text { No. of } \\
\text { mated } \\
\text { females }\end{array}$ & $\begin{array}{c}\text { No. of } \\
\text { females } \\
\text { with } \\
\text { implantations }\end{array}$ & $\begin{array}{c}\text { No. of } \\
\text { fertile } \\
\text { males }\end{array}$ & $\begin{array}{c}\text { Fertility } \\
\text { (\%) }\end{array}$ \\
\hline $\mathbf{0}$ (control) & 6 & 0 & 22 & 16 & 6 & 100 \\
0.5 & 10 & $31-90$ & 24 & 4 & 2 & 20 \\
& & $91-120$ & 13 & 10 & 7 & 70 \\
1.0 & 10 & $31-90$ & 21 & 1 & 1 & 10 \\
& 12 & $91-120$ & 13 & 5 & 3 & 30 \\
1.5 & 12 & $31-90$ & 23 & 0 & 0 & 0 \\
& & $91-120$ & 14 & 0 & 0 & 0 \\
\hline
\end{tabular}

\section{Comparison of wires of different composition}

As shown in Table 2, similar stainless steel and silver devices had little or no effect on fertility in rats. 
Table 2. Fertility performance of male rats with intravasal metallic devices

( $1.5 \mathrm{~cm}$ long, $0.14 \mathrm{~mm}$ diameter)

\begin{tabular}{lccccr}
\hline \multicolumn{1}{c}{ Treatment } & $\begin{array}{c}\text { No. of } \\
\text { males }\end{array}$ & $\begin{array}{c}\text { No. of females } \\
\text { mated/no. } \\
\text { tested }\end{array}$ & $\begin{array}{c}\text { No. of females } \\
\text { with } \\
\text { implantations }\end{array}$ & $\begin{array}{c}\text { No. of } \\
\text { fertile } \\
\text { males }\end{array}$ & $\begin{array}{c}\text { Fertility } \\
(\%)\end{array}$ \\
\hline None (controls) & 5 & $24 / 43$ & 16 & 5 & 100 \\
Copper & 12 & $37 / 59$ & 0 & 0 & 0 \\
Stainless steel & 10 & $34 / 62$ & 25 & 9 & 90 \\
Silver & 12 & $36 / 68$ & 28 & 12 & 100 \\
\hline
\end{tabular}

\section{Copper release}

Experiment III results are given in Table 3. When the high release during the first 30 days is taken into account, the actual amount of copper released during the period of 30-90 days after insertion was calculated to be about $4.38 \mu \mathrm{g} /$ day.

Table 3. Release of copper (mean \pm s.e.m.) from copper wires inserted into the vasa deferentia of male rats for 1 or 3 months

\begin{tabular}{|c|c|c|c|c|}
\hline \multirow{2}{*}{$\begin{array}{l}\text { Duration of } \\
\text { insertion } \\
\text { (months) }\end{array}$} & \multirow{2}{*}{$\begin{array}{l}\text { No. of } \\
\text { males }\end{array}$} & \multicolumn{2}{|c|}{$\mathrm{Cu}$ content $(\mathrm{mg})$} & \multirow{2}{*}{$\begin{array}{c}\text { Copper released } \\
(\mu \mathrm{g} / \text { day })\end{array}$} \\
\hline & & Before insertion & After removal & \\
\hline $\begin{array}{l}1 \\
3\end{array}$ & $\begin{array}{l}10 \\
10\end{array}$ & $\begin{array}{l}2.14 \pm 0.012 \\
2.00 \pm 0.029\end{array}$ & $\begin{array}{l}1.792 \pm 0.017 \\
1.389 \pm 0.036\end{array}$ & $\begin{array}{r}11.60 \pm 0.66 \\
6.79 \pm 0.48\end{array}$ \\
\hline
\end{tabular}

\section{Onset of contraceptive action}

The control, sham-operated rats gave fertile matings which were uniformly distributed throughout the test period. The performance of the rats with a copper device is presented in Table 4. Fertile matings occurred until 20 days after operation but thereafter all matings were infertile. The total number of fertile and infertile matings between Days 11 and 25 was significantly less than that in any 15-day period after Day $30(P<0.05$; Student's $t$ test).

Table 4. Onset of contraceptive action in male rats with a $1.5 \mathrm{~cm}$ intravasal copper wire

\begin{tabular}{ccc}
\hline & \multicolumn{2}{c}{ Matings } \\
\cline { 2 - 3 } Days & Fertile & Infertile \\
\hline $11-15$ & 3 & 0 \\
$16-20$ & 1 & 0 \\
$21-25$ & 0 & 1 \\
$31-35$ & 0 & 3 \\
$36-40$ & 0 & 4 \\
$41-45$ & 0 & 8 \\
$46-50$ & 0 & 4 \\
$51-55$ & 0 & 5 \\
$56-60$ & 0 & 5 \\
$61-65$ & 0 & 2 \\
$66-70$ & 0 & 6 \\
\hline
\end{tabular}




\section{Restoration of fertility after removal of the device}

The rats had all been infertile during the time the copper wire was inserted. As shown in Table 5, many of the males were fertile again by 90 days after removal of the device.

Table 5. Fertility performance of male rats after removal of an intravasal copper device $(1.5 \mathrm{~cm}$ length)

\begin{tabular}{lccccc}
\hline \multicolumn{1}{c}{ Treatment } & $\begin{array}{c}\text { No. of } \\
\text { males }\end{array}$ & $\begin{array}{c}\text { No. of } \\
\text { females } \\
\text { mated/no. } \\
\text { tested }\end{array}$ & $\begin{array}{c}\text { No. of } \\
\text { females } \\
\text { with } \\
\text { implantations }\end{array}$ & $\begin{array}{c}\text { No. of } \\
\text { fertile } \\
\text { males }\end{array}$ & $\begin{array}{c}\text { Fertility } \\
(\%)\end{array}$ \\
\hline Sham-operated (control) & 5 & $26 / 36$ & 19 & 5 & 100 \\
Intravas Cu wire removed & 9 & $32 / 51$ & 15 & 6 & $66 \cdot 67$ \\
\hline
\end{tabular}

\section{Discussion}

The results of Exp. I show that the best retention and contraceptive effect was obtained with the wire of greatest surface area. This must be achieved mainly by increased length of the wire because the diameter has to be such that it does not occlude the lumen of the vas. The contraceptive effect of copper IUDs in women has also been shown to be roughly proportional to the surface area of copper in contact with the endometrium (Zipper, Tatum, Medel, Pasten \& Rivera, 1971). Corrosion, followed by breakage of the pure metallic copper wire, appears to be a factor responsible for the decrease in contraceptive effectiveness which is correlated with the duration of its use. In women the fragmentation of the wire of copper IUDs during the 12th month of use and the $30 \%$ breakage during the 3rd and 4th year were associated with an increase in pregnancy rate (Jain, 1975; Timonen, 1976).

The release rates obtained in vivo suggest that the intravas device would be effective for about 1 year, but breakage of the wire occurred during the 3rd and 4th month of use. Similarly, on the basis of release rate the life-span of Tcu- 200 has been estimated to be slightly over 7 years (Timonen, 1976), but the life of the devices in practical terms is related to the corrosion and breakage. Improved life-spans of IUDs have been obtained by using another substance for the core (Sikov, Divine \& Hackett, 1976). This is not possible for an intravas device, at least in rats, in which thickness of the wire is limited and we are now studying a copper-silver alloy.

Although matings immediately after insertion of the device were few, the antifertility effect seems to be operative after Day 20. The reduced numbers of matings were probably due to local trauma to the vasal tissue caused by the presence of a foreign body in the vas. This was also evident in the histological sections of the vas deferens in that there was oedema of the sub-epithelial layer during the first 2 months after insertion of the device. There was no obvious oedema after 4 months. Such oedema could have affected the sperm flow, rather than the mating behaviour, resulting in an absence of spermatozoa in the vaginal smears. Many females did in fact become pseudopregnant. Granulomata were observed in animals with copper devices and silver devices and granuloma formation could not have been responsible for the contraceptive action.

The $67 \%$ of fertile animals after removal of the device is much higher than that reported after vasovasostomy of men (see Hulka \& Davis, 1973). The reversal of fertility with the present device may be further improved by reducing trauma by use of microsurgical techniques employing stereo-optical surgical microscopes during insertion and removal operations, and also by using an animal model which may not pose as serious a problem of granuloma formation as do rats. 
From the results presented, it may be concluded that an intravas copper device appears to be a promising method for reversible control of fertility in the male. Further work in monkeys and men is needed to prove the usefulness of the approach in developing a long-term reversible method for human contraception.

This work was supported by grants from the World Health Organization (WHO-CCRT), Geneva, and the Director General of Health Services, New Delhi, India.

\section{References}

Ahsan, R.K., Farooq, A., Kapur, M.M. \& Laumas, K.R. (1976) The effect of intravasal copper on the fertility of rats. J. Reprod. Fert. 48, 271-274.

Hulka, J.F. \& Davis, J.E. (1973) Sterilization of men. In Human Reproduction, pp. 427-446. Eds E. S. E. Hafez \& T. N. Evans. Harper \& Row, New York.

Jain, A.K. (1975) Safety and effectiveness of intrauterine devices. Contraception 11, 243-259.
Sikov, M.R., Divine, J.R. \& Hackett, P.L. (1976) Studies of duplex (copper-coated) wires for use in intrauterine devices. Contraception 13, 55-63.

Timonen, H. (1976) Copper release from copper-T intrauterine devices. Contraception 14, 25-38.

Zipper, J.A., Tatum, H.J., Medel, M., Pastene, L. \& Rivera, M. (1971) Contraception through the use of intrauterine metals. 1. Copper as an adjunct to the ' $T$ ' device. Am. J. Obstet. Gynec. 109, 771-774.

Received 24 September 1979 